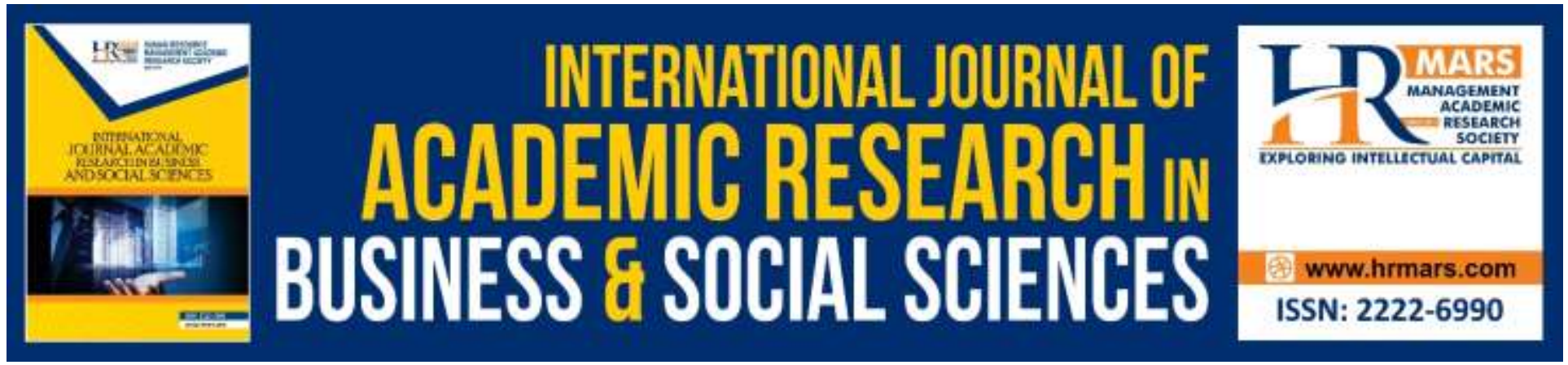

\title{
Record and Information Management among SMES in Ghana: Evidence from Selected SMES in the WA Municipality of Ghana
}

\author{
Suleman Yussif, Appiah Kusi and Alhassan Ismail
}

To Link this Article: http://dx.doi.org/10.6007/IJARBSS/v9-i8/6234

DOI: $10.6007 /$ IJARBSS/v9-i8/6234

Received: 09 May 2019, Revised: 18 June 2019, Accepted: 30 July 2019

Published Online: 24 August 2019

In-Text Citation: (Yussif, Kusi, \& Ismail, 2019)

To Cite this Article: Yussif, S., Kusi, A., \& Ismail, A. (2019). Record and Information Management among SMES in Ghana: Evidence from Selected SMES in the WA Municipality of Ghana. International Journal of Academic Research in Business and Social Sciences, 9(8), 184-199.

\section{Copyright: (C) 2019 The Author(s)}

Published by Human Resource Management Academic Research Society (www.hrmars.com)

This article is published under the Creative Commons Attribution (CC BY 4.0) license. Anyone may reproduce, distribute, translate and create derivative works of this article (for both commercial and non-commercial purposes), subject to full attribution to the original publication and authors. The full terms of this license may be seen

at: http://creativecommons.org/licences/by/4.0/legalcode

$$
\text { Vol. 9, No. 8, 2019, Pg. } 184 \text { - } 199
$$




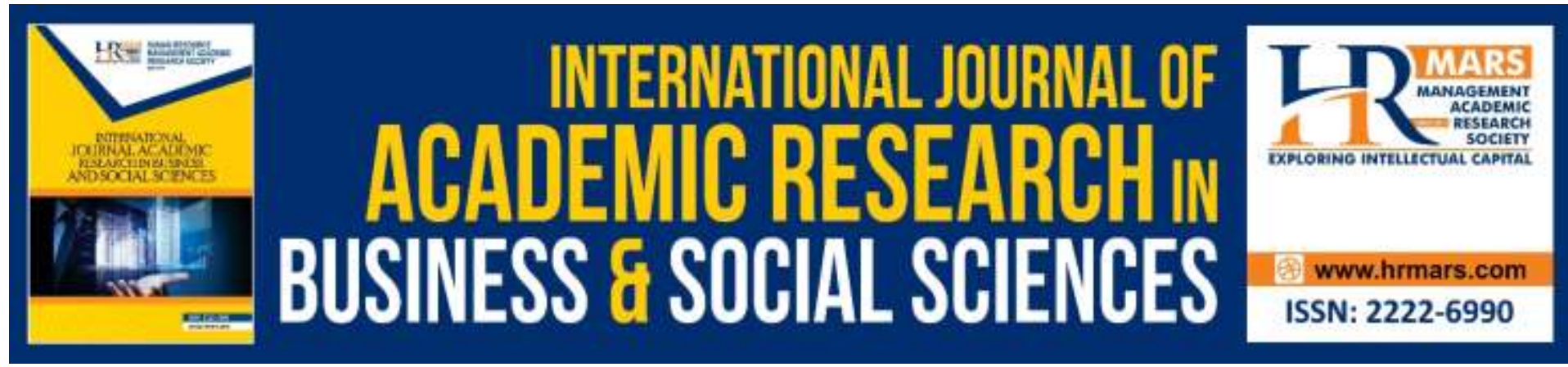

\title{
Record and Information Management among SMES in Ghana: Evidence from Selected SMES in the WA Municipality of Ghana
}

\author{
Suleman Yussif ${ }^{1}$, Appiah Kusi ${ }^{1}$ and Alhassan Ismail ${ }^{2}$ \\ ${ }^{1}$ Lecturer, ${ }^{2}$ Assistant Registrar, WA Polytechnic, Wa, Ghana
}

\begin{abstract}
SMEs represent a significant constituency among the development vehicles of Ghana. They are described as the engine of growth for the local economy with several central government interventions in that sector. Research however reveals that, the rate of business collapse in this sector is high, thereby negating the interventions instituted to facilitate the growth of the sector. Besides, mismanagement and poor record keeping practices have been identified as a bane in the sector contributing to the rapid collapse of entities. The main purpose of this study was to explore the record keeping practices among SMEs in the Wa Municipality of Ghana. The study therefore made use of an exploratory design to collect information from respondents about the record keeping activities of their businesses. Findings of this study reveal that, most respondents did keep some form of record in their business as contradicting the position of literature. Again, the study shows that SMEs in the Municipality keep predominantly financial records for reasons such as inventory, personal, administrative and on financial principle. Predominant financial records such as day books, cash books and to a lesser extent, ledgers were seen as imperative for proper management of many businesses in the Municipality. These financial records and subsequent financial statements were kept and prepared according to the needs of the selected SMEs and not in conformity with standards.
\end{abstract}

Keywords: SMEs, Record keeping, Ghana

\section{Introduction}

Small and Medium Enterprises (SMEs) occupy a place of pride in virtually every country or state. Because of their significant roles in the development and growth of various economies, SMEs have aptly been referred to as "the engine of growth" and "catalysts for socio-economic transformation of any country" (Mbroh \& Attom, 2012). SMEs represent a veritable vehicle for the achievement of national economic objectives of employment generation and poverty reduction at low investment cost as well as the development of entrepreneurial capabilities including indigenous technology (Aryeetey, 2001). 
Other intrinsic benefits of vibrant SMEs include access to the infrastructural facilities occasioned by the existence of such SMEs in their surroundings, the stimulation of economic activities such as suppliers of various items and distributive trades for items produced and or needed by the SMEs, stemming from rural urban migration, enhancement of standard of living of the employees of the SMEs and their dependents as well as those who are directly or indirectly associated with them (Beck, DemirgucKunt, \& Levine, 2003; Snodgrass \& Winkler, 2004).

Additionally, SMEs play key roles in generating employment, promoting innovation, creating competition and generating economic wealth (Umar, 1997). Recognition of the importance of this sector as a major contributor to job creation and economic growth especially during the 1990s, has led to a dramatic increase in the academic research being carried out on small and medium enterprises (Gunu, 2004). In the 1990s small business become one of the mainstays of many economies (Jenning \& Beaver, 1995). The sheer number of SMEs makes them an important constituent of the local, regional and national economies and as such, a potential target for policy intervention (Schmitz, 1995).

It is established that, more than $80 \%$ of the work force in Ghana are employed by this sector (Barr, 2000). However, in spite of the enormous potential and actual benefits of SMEs to the economies of various countries, recent studies show that $60 \%$ of the SMEs fail within the first five years of operation (Boachie-Mensah \& Marfo-Yiadom, 2005). Studies also show that it is hard for the SMEs to access finances from the financial institutions since they lack proper financial records as a requirement (Williams, Haka, Bettner \& Carcell, 2008). The SMEs inability, many times to live beyond their first few months of existence has been attributed partly to lack of finance. To become successful and be able to contribute meaningfully to the Ghanaian economy, SMEs must attract and secure finance all by themselves (Amoako, 2013).

According to Okoli (2011), for the small scale enterprises to efficiently play the mentioned roles there should be an orderly method for gathering and organizing information about the various business transactions. This can only be done by the use of adequate accounting system. The maintenance of proper records may help companies to avoid paying unnecessary fines and lawsuit settlements costs. Furthermore, records would provide evidence of transparency and accountability of private business to stakeholders (Chachage \& Ngulube, 2006) It has generally been noted that, accurate business records can be a valuable source of information and can tell the story of the business pattern of success or lack of it. Unfortunately, many business owners' especially small and medium enterprises are poor records keepers. This hinders many developments including preventing them from determining the fair value of their business for merger or acquisition purposes or even to a potential buyer (Ibenta, 2005). Keeping proper and organized records help firms for proper planning and forecasting. SMEs need to put proper plans in place for the use of limited resources and to meet future threats that may come to distort the firms operations (Ibenta, 2005). Keeping well and organized records also ensures that, small and medium enterprises can answer questions pertaining to returns that are selected for examination or prepare a response if notices are received from revenue authorities. McCannon (2002) argues that, many SMEs fail because owners could not make timely and key managerial decisions resulting from the lack of adequate records. Given the 
benefits of record keeping, one would therefore wonder why some owners of SMEs fail to maintain books of accounts (Musah \& Ibrahim, 2014). This question is very critical and serves as the main thrusts of this study.

The forgone discussion has established without doubt that SMEs are critical instruments if well managed could be a panacea to development in many countries. In Ghana, the three northern regions continuously remain in the bottom of development and poverty tables. The Upper West region in particular has consistently been referred to as the poorest in the country (Steel \& Andah, 2003; Quansah, Amanquah \& Aikins, 2012). The efforts to harness all potential for development is therefore very imperative. As such, creation of avenues for SME growth has been the priority of many governmental policies. This has led to a significant increase in the emergence of small informal sectors enterprises. According to the National Board for Small Scale Industry (NBSSI, 2009), more than two thirds of business in the Upper West region especially in the Wa municipality are small and medium enterprises, and employ over $80 \%$ of the work force in the municipality. However, the impact of these businesses has not been as expected since poverty levels remain very high in the region. Many issues have been attributed to this phenomenon (GSS, 2011, Mbroh \& Attom, 2012). Among them are the low capital base of these businesses, the lack of credit facilities for expansion, over and under taxation, improper entrepreneurial practices and business development skills among others.

Most of these challenges have been duly researched and recommendations proffered (see Nayak \& Greenfield, 1994; Holmes \& Nicholls, 1989, Mitchell et al. 1999). However, one critical issue which has been consistently neglected by officials and researchers at large has been the nature of record keeping practices among small scale enterprises and its impact on their businesses. Very few studies (Maseko \& Manyani, 2011; Okoli, 2011, Mbroh \& Attom, 2012; Amoako, 2013; Musah \& Ibrahim, 2014) have been done to identify the role proper record keeping play in the success or failure of small businesses. There are also very few studies on records keeping practices of SMEs in the Upper West region. This study therefore seeks to fill this gap by examining the records keeping practices among the various small and medium enterprises in the Wa Municipal area. The study seeks to critically examine the record keeping practices of SMEs in the Wa Municipality of Ghana.

The rest of this paper is organized into five sections, section two reviews related literature on SME record keeping practices, part three presents the methods and procedures adopted for data collection and analysis, part four presents a discussion of results, and part five which is the final part of this paper presents the conclusions and implications of the study.

\section{Literature Review \\ Record Keeping Practices among Small and Medium Enterprises}

According to Holt (2008) several record keeping systems might be adopted by small and medium enterprises to achieve different goals including To enable a business to control its activities, safeguard its assets, and monitor profitability thus informing its strategic direction. This is integral with the creation and maintenance of an audit trail of transactions on a historic and current basis in line with good business practice. To satisfy external auditors, company directors, shareholders, 
creditors, investors and other interested stakeholders that the records reflect a true and fair value of the business. To enable a business to meet various statutory requirements, including requirements for both Revenue authorities and external auditors. Holmes and Nicholls (1989) conclude that the volume of accounting practices in SMEs is dependent on a number of operating environmental factors that include size of the business, business age and industrial grouping. They further argue that most owners and managers of SMEs engage public accountants to prepare required information and that owners and managers search for additional information, but only to a limited extent. Ismail and King (2007) conclude that the development of a sound accounting information system (AIS) in SMEs depends on the owners' level of accounting knowledge. Keasy and Short (1990), report that small firms use professional accounting firms for preparation of annual reports and for other accounting needs.

Evaraert et al. (2006) and Jayabalan and Dorasamy (2009) however argue that the high cost of hiring professional accountants leaves SME owner-managers with no option but to relegate accounting information management. Zhou (2010) proposes the use of accounting software by owner managers in SMEs to improve accounting practices but laments that developers of accounting software are yet to produce the mediumsized software for SMEs.

An early study of users of financial statements in SMEs revealed that owners, managers, tax authorities and lenders are the main users. According to Olson et al. (2004), contemporary studies are discovering that the number of users of accounting information in SMEs is increasing to include venture capitalists and customers in supply-chains. Wichman (1983) concludes that accounting and marketing pose major challenges to management of SMEs and recommends that managers or owners in SMEs must learn about accounting or hire experts. Walhlstedt (1996) believes that conventional accounting reports play a significant role in SMEs but argues that the reports must be adjusted in order for them to be understood, proposing the use of the cash basis rather than the accruals basis.

McMahon (1999) argues that financial reporting practices in SMEs seem to fall short of what is dictated by various external financial reporting imperatives that exist for them, further arguing that owner-managers appear particularly reluctant to produce financial reports which might become accessible to outside parties either directly or through the offices of regulatory authorities. Income tax systems in most OECD countries are accrual based (EC. 2008). Under cash accounting, income tax is paid on revenues only when cash is received, and input costs are claimed only when cash is paid out. Cash accounting systems targeted at SMEs to compute taxable income based on entries of revenues actually received and costs actually incurred. Cash basis can significantly reduce compliance costs depending on the additional supporting documentation that SMEs as taxpayers are required to keep and maintain. Other simplification measures may include simplified book-keeping requirements (McMahon, 1999).

There seems to be some consensus on the significance of financial accounting systems to business success (Amoako, 2013). Some researchers assert that the quality of financial accounting information employed within the SMEs sector has a positive 
relationship with the performance of the entity (see, Lybaert, 1998; Holmes \& Nicholls, 1989).

Studies assert that the high incidence of failure among SMEs could be attributed to the poor accounting systems used by these enterprises (see, for example, Ofonagoro, 1983). Those studies recount that since accounting systems play a key role in determining business growth and profitability, there is a need to evaluate the accounting systems used by SMEs. This is important because for optimum business growth, SMEs must make use of a system of accounting which will enable them determine the volume of sales, profits (or loss), assets and liabilities at any given time (Amoako, 2013).

\section{Challenges of Record Keeping}

The above discussions have clearly shown that keeping records within the SME sector is imperative. However, a number of them have been seen not to keep records at all (Musah \& Ibrahim, 2014; Amoako, 2013; Okoli, 2011). A number of reasons have been adduced for this situation. According to Kyobe, Molai and Salie (2009), some major challenges in managing electronic records in academia relate to the nature of the records kept and used, where they are located, policy issues, accountability and responsibility of users, and compliance with rules and regulations. In their study of Management of Business Records in Tanzania, Chachage and Ngulube (2006) discovered that the key problems to managing records included inadequate policies on records management, difficulty in managing electronic records, issues with compliance to standards, poor staffing and professionalism and poor disposition and retention of records. Other studies have found that lack of record keeping knowledge, low educational levels, cost of hiring professional accountants and owners attempt to keep records in their memory are challenges that result in poor records keeping among SMEs (Maseko \& Manyani 2011; Mbroh \& Attom, 2012; Aryeetey, 1994).

In short, the main challenges of record keeping in the SME sector can be said to be lack of knowledge, education or technical competence, inadequate logistical capacity as well as failure to recognize the essence of records and poor regulatory framework or standardization.

\section{Methodology}

This study leans to the positivist paradigm to carry out activities aimed at achieving the set objectives of the research. This paradigm stipulates for the collection of a substantial amount of data for processing and analysis. With this approach, conclusions can be generalized for the entire population based on the results obtained from the sample selected. This paradigm was selected because it is reputed to be more objective and eliminates biases on the part of the researcher in comparison to other paradigms. The study made use of an exploratory design which enabled information to be collected from respondents about the record keeping activities of their businesses. The main study population was drawn from owners, managers or proprietors of SMEs found in the Municipality. The target population was all small business operators within the geographical location of Wa and who were registered with the various agencies, like the Ghana Revenue Authority, the National Board for Small Scale Industries, and the Wa Municipal Assembly. A sample of small business 
owners participated in this study. As at the time of carrying out the study, a sampling frame of all small businesses in the Municipality could not be obtained. An initial figure of 659 was obtained from the Municipal Assembly but the figure proved to be difficult to verify since the list of businesses provided did not tally with the figure provided. As a result the researcher contacted the various registered business associations to get their members to participate in the study.

Pursuant to the above, six main recognized associations within the municipality were identified. They include Retailers Association, Dressmakers and Tailors Association, Food Vendors Association, Craft Artisans Association, Auto Repairers Association and Spare parts dealers association. Each of these associations was allotted 20 respondents. Hence a total of 120 respondents were expected to participate in the study. The respondents were purposively selected on the bases of their type of business and the association they belonged to. The main instrument for data collection was a questionnaire. The questionnaire had a series of close and open ended questions aimed at eliciting information about SMEs and their record keeping practices. Each respondent was contacted and his or her consent sought, after which he or she was given a questionnaire.

\section{Results and Discussion \\ Record Keeping Practices of SMEs}

A major objective of the study was to describe the record keeping practices of SMEs in the municipality. To do this the study examined whether SMEs kept records or not, the type of records kept, whether the records conformed to international standards and how accessible their records were. We begin with whether they kept records or not. Divisive

Figure 1: Record Keeping

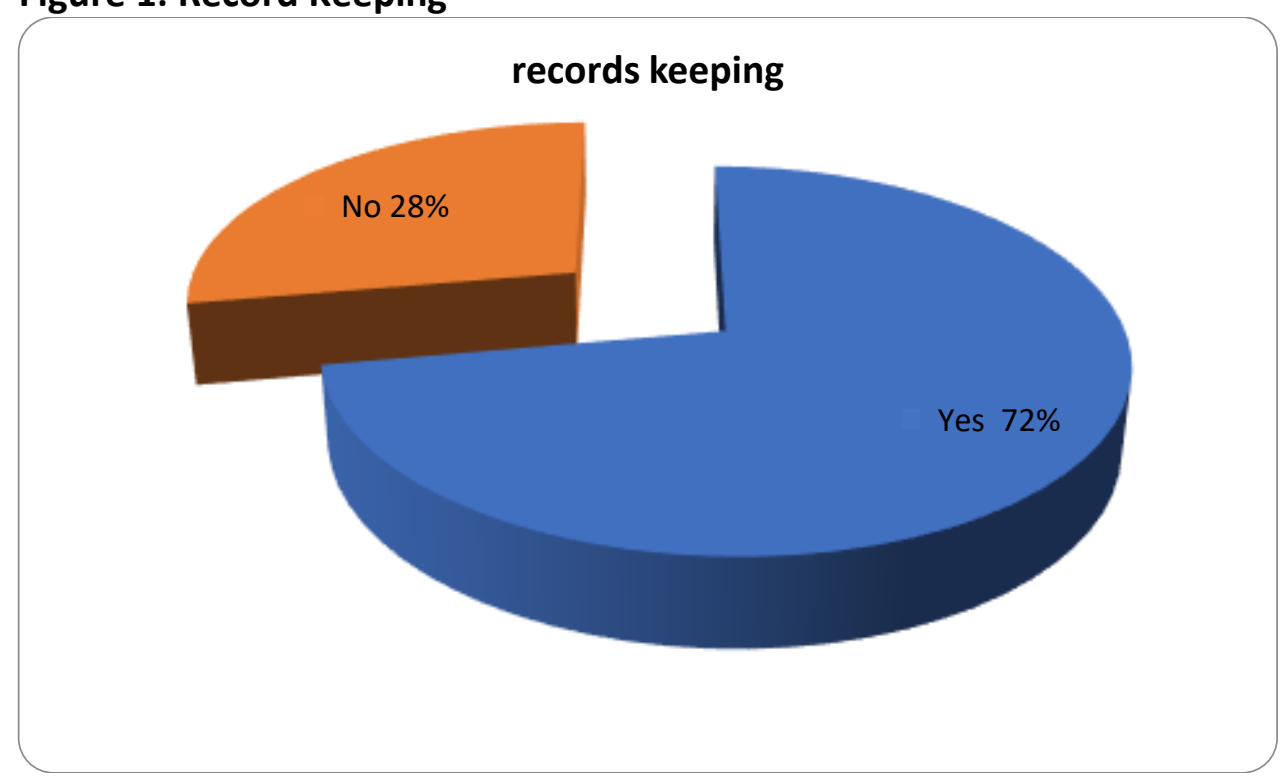

Source: Field Data; 2017

Figure 1 above shows results on whether respondents kept records or not. It is obvious from the figure that the majority (72\%) of respondents admitted to keeping one form of record or another. Only 28 percent reported that they do not bother to keep any 
records at all. This shows that most respondents did keep some form of record in their business. The reasons for keeping these records and the advantages derived for doing so will be explored subsequently. Those who failed to keep records stated a number of challenges associated with doing so. These difficulties are also further explored in the last section of this chapter.

This result is contrary to the assertion made by McMohan, (1999) that most SMEs do not keep records.

\section{Types of Records}

Following whether records are kept or not, the study looked at the type of records kept by SMEs in the municipality. The data was coded as financial, inventory, personal and administrative reasons. The results are shown in Table 1.

Table 1: Types of Record Kept

\begin{tabular}{lcc}
\hline Variables & Frequency & Percentage \\
\hline Financials & 37 & 47 \\
Inventory & 16 & 21 \\
Personal & 24 & 31 \\
Administrative & 1 & 1 \\
\hline Total & 78 & 100 \\
\hline
\end{tabular}

Source: Field Data; 2017

Table 1 shows the main types of records kept by respondents who reported that they did keep them. As indicated in the table, for those who keep records, only one percent did so for administrative reasons. The rest did so for reasons such as inventory purposes (21\%), personal purposes (31\%) and 47 percent did so on financial principle. Financial records such as for example the sales day book, purchases day book, cash receipt book, cheque payments book, petty cash book, general journal, nominal ledger, debtors' ledger among others are seen as imperative for proper management of many businesses (McMahon, 1999, Musah \& Ibrahim, 2014). It is therefore not surprising that it dominated the types of records kept by respondents in the sample. Other forms of records such as personal records were kept in conjunction with financial records, these included registers, log books, among others. Inventory of sheets were also kept to monitor product in stock and out of stock. The record type with the least number of responses was administrative records. This was rather surprising since one would expect such records to be significant to the day to day operations of businesses. The only administrative record encountered was that of the daily attendance book reported by only one respondent. Admittedly most respondents did not find this very necessary because they felt that the other forms of records namely financial, inventory and personal records were enough to see to the smooth running of their businesses.

\section{Conformity to Standards}

The next issue explored in addition to type of record was the standard of the record kept. This was done to ascertain whether records kept were up to the standard of the International Financial Reporting Standards (IFRS). The results are summarized below. 
Figure 4: Conformity to IFRS

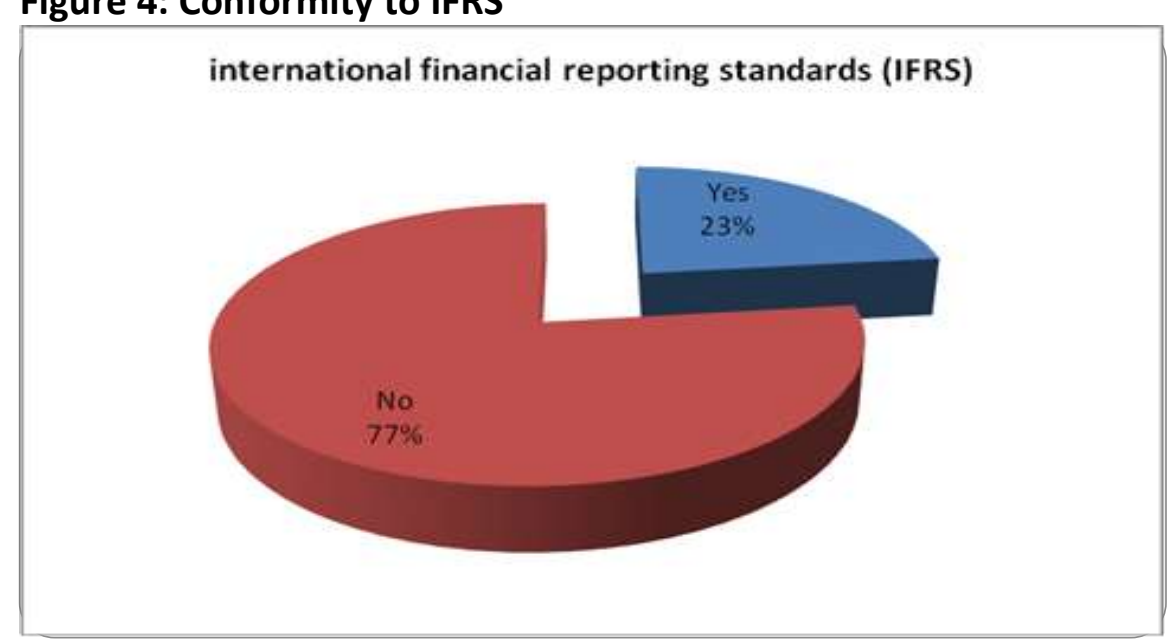

Source: Field Data; 2017

It is clear from the figure that the majority of respondents did not follow the IFRS standard of reporting. Only 23 percent admitted to knowing what it was and actually making efforts to comply with it. The rest of the respondents, that is 77 percent, were not even aware of what it was let alone comply with it. This result is not surprising at all since the main standards were introduced a few years back in 2009 and the IFRS for SMEs in 2015 (IFRS for SMEs in 2015). The aim of the reporting standard was to make SME records to meet the needs of entities whose securities trade in public capital markets (Maseko \& Manyani, 2011). And in the case of SMEs to meet certain minimum content requirements in order to ensure comparability with financial statements of other entities and with the same entity for prior periods (Reference).

\section{Accessibility of Records}

After examining whether records kept by the SMEs conformed to international standards or not, the next issue investigated was the level of accessibility of the records kept. That is the study sought to find out how accessible records kept were to business owners themselves and to any other party which may be interested in them. The details of the results are presented in the following figure. 
Figure 5: Accessibility of Records

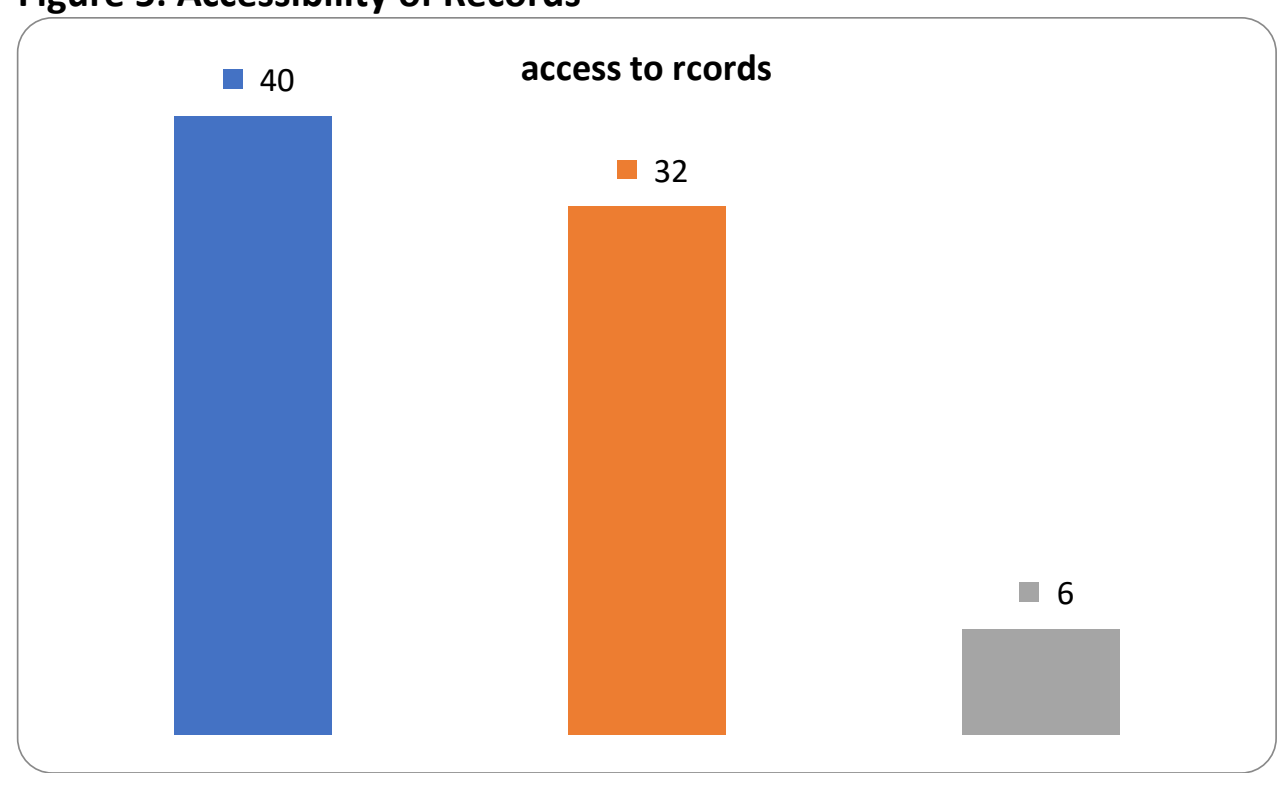

Source: Field Data; 2013

From Figure 5, it can be asserted that the majority of respondents who kept records had records which were very accessible. That is, about 40 respondents representing 51 percent of those who kept records had very accessible records. The rest of them had quite accessible records $(32,41 \%)$, while those whose records were difficult to access numbered 6 persons representing 8 percent. The results implies that about 92 percent of SMEs who kept records kept them in ways and formats that made them at least quite accessible for themselves and others. This is very important because why keep records if they are not readily accessible? Those who reported that their records were difficult to access indicated that this was as a result of some technical difficulties and that it was their ambition to have that rectified as soon as possible. They cited lack of space, personnel and other equipment as the main factors contributing to their inability to make their records very accessible.

\section{Reasons for Keeping Records}

At the heart of this paper is the effort to explore why SMEs do keep records and its attendant benefits or costs to them. This section presents the results on reasons why records are kept and the benefits derived for doing so. Table 3 presents results on the reasons why SME owners will keep records. From the table, the dominant reason why records are kept was for purposes of determining business growth. This is because nearly 50 percent of respondents reported that was why they kept records. The next major dominant reason why records are kept is a combination of purposes with about 25 percent of respondents attesting to this reason. Another reason why records are kept was to help in identifying fast moving items, with about 19 percent of respondents making submissions to that effect. The remaining reasons were for tax purposes (4\%) and other unspecified reasons 5 percent. 
Table 3: Reasons for Keeping Records

\begin{tabular}{lcc}
\hline Variables & Frequency & Percentage \\
\hline Identify fast moving items & 20 & 19 \\
Determine business growth & 51 & 48 \\
For tax purpose & 4 & 4 \\
Others & 5 & 5 \\
All of these & 21 & 25 \\
\hline Total & 107 & 100 \\
\hline
\end{tabular}

\section{Benefits of Keeping Records}

\begin{tabular}{lcc}
\hline Variable & Frequency & Percentage \\
\hline Simple to keep & 7 & 6 \\
Less costly & 3 & 4 \\
Help run business & 88 & 81 \\
Help for tax computation & 7 & 6 \\
Stewardship & 3 & 3 \\
\hline Total & 108 & 100 \\
\hline
\end{tabular}

Source: Field Data; 2013

The results implies that for respondents who kept records, their primary interest was to use the records to determine the growth or otherwise of their business. Thus records served as a tool for evaluating business performance. Respondents reported that keeping records helped them to keep track of their areas of expansion and other areas which needed attention. Another reason for keeping records was to identify fast moving items; this was peculiar to business in the commerce category. Since they dealt in sales of various commodities, it was prudent for them to be able to determine which items are in stock, which items are out of stock and for other similar reasons. About a quarter of respondents also submitted that they kept records for all the various reasons suggested. They could not single out a particular reason why they kept records but asserted that all the reasons enumerated were applicable. A small fraction of respondents stated other reasons most particularly for purpose of applying for a loan or to seek licenses. Interestingly and contrary to expectations, only 4 percent of respondents kept records solely for tax purposes. One would have expected that keeping proper records for tax reasons will be a major preoccupation of SMEs. This was not the case however. The exact relationship between record keeping and taxation will be explored subsequently. Haven examined why records were kept, respondents were further asked to indicate the benefits or advantages that could be derived from keeping records. The results are presented in the above table.

The table shows that various advantages have been attributed to keeping records. However, the most significant among them is that it helps in the running of the business. Thus a whopping 81 percent of the respondents believed that the greatest advantage of record keeping in the SME sector is because it contributes to the smooth running of the business. Other advantages outlined include; simplifies activities of the business (6\%), help in tax computation (6\%), reduces cost of operations (4\%), and improve stewardship (3\%). 
Thus, 19 percent of respondents attributed the advantage of keeping records to other factors aside its contribution to running the business. Again taxation served as a minimal advantage for record keeping. Majority of the respondents said records helps to run businesses for the fact that, people feel comfortable if they know how their monies are used and whether their businesses are growing among other reasons. These responds in many ways affirms the view of Michael, (2009), and William, et al (2008).

\section{Conclusions}

This study examined record keeping practices among SMEs in the Wa municipality. The main objective of the study was to identify the types of records kept by SMEs and how these impacts on their business. Generally taxation was used as the main benchmark to assess the impact of record keeping on small businesses.

The study employed an exploratory design which aimed at highlighting activities of SMEs in the Wa municipality with regards to their record keeping practices. Using a sample of 108 small business owners conveniently selected, questionnaires and some instances structured interview guides were the main instruments used to collect data. Some observation of activities and premises of business was also done to augment the two instruments. Data collected was process using SPSS version 17 and presented in tables, graphs and charts. The findings of the study are presented in the following section.

\section{Major Findings}

Small and Medium enterprises in the municipality vary widely and are numerous. This confirms the initial assertion that there is an increase in the number of small business in the region. The main forms of business although varied could be grouped into two main categories, artisanship and trade. The artisanship category could be further split into two namely; craft and skill

The majority of SMEs in the municipality earn less than a thousand cedis monthly. This means that they are generally small or micro enterprises. Additionally, most of the businesses were in their first decade confirming the fact that they are relatively young and of recent establishment.

The majority of businesses do keep records mostly in the form financial records as well as other purposes like inventory and personnel information. Most of these records were kept without recourse to international reporting standards. These records also tended to be quite accessible and easy to reach.

The main reason why a business owner kept records was to enable him or her keep track of the growth of his or her business. Records were kept to keep tabs on fast moving items, demand streams and other areas all in line with running the business. The single most important advantage derived from keeping records according to the respondents was because it helped in running their business.

Contrary to earlier assumptions that taxation will be a significant reason why business keep records, the finding to this is effect is that taxation only forms a minimal reason why records are kept by business owners in the municipality. The impact of taxation on nature and type of records kept was rather nominal. This may be as a result of the 
fix rate of taxes levied on small business. The main forms of taxes paid included property rates, licenses and income tax. Thus tax liabilities were not determined using income levels of the businesses. This could pose a problem since some businesses may either be overtaxed or under taxed.

The main challenges associated with record keeping among small business were technical ineptitude, financial constraints and purported time wasting. Most businesses lacked the requisite technical competence and financial clout to keep standard records. As such they kept their records in the simplest forms or formats available. Time wasted in filling out forms or writing down information for the purpose of keeping records was also found to be a major bottleneck for record keeping.

\section{Conclusions}

The Wa Municipality is indeed witnessing a growth of small enterprises of various forms and sizes. These businesses although micro in size, have the potential of growth and thereby increase the employment opportunities for the teeming unemployed youth. However, their record keeping practices lack the necessary standardization and the potential of keeping good records have not been fully appreciated.

The advantages for keeping records have been narrowly construed to be only essential in running business to the neglect of other areas such as taxation and regulation. Although business growth and smooth running of business are two very important reasons why records should be kept, taxation, personnel information and regulatory obligations are other good reasons why records should be kept. It is therefore imperative for business owners in the municipality together with the regulators and monitors of these businesses to ensure or insist on good record keeping practices.

\section{Contributions of the Study}

The study has broadened the extant literature in the field by elucidating on how SMEs in Ghana manage their records and information and the effects that has on the financial performance of SMEs. The study has also explained the challenges bedeviling SMEs that did not keep proper records of their activities. It has also shed further light on the need for SMEs to keep proper results of their activities to ensure proper planning and control of operations, and the type of records SMEs should keep.

\section{Implications for Policy Research and Practice}

In view of the above findings and conclusions, the following recommendations are imperative; The municipal assembly and other regulators of small businesses must ensure that all SMEs keep accurate and proper records of their businesses. This will allow all SMEs to derive the benefits of record keeping. Various stakeholders (Bank of Ghana, Ministry of Finance, Ministry of Trade, and GRA) must assist SMEs to keep records. The assistance could be in the area of capacity building, provision of technical equipment as well as financial assistance. In line with this, stakeholders of the SME sector could organized training workshops for business owners to build their capacity on record keeping and also to impart to them the requisite skills and standards of record keep.

A general, uniform, simple and cost effective records keeping format must be developed by the Bank of Ghana and its allied agencies and made accessible to 
business owners to aid their record keeping. The importance of keeping records must also be emphasized to business owners. Small business owners must make it a point to obtain both the necessary training and logistics to enable them improve upon their records keeping. They can obtain both electronic and non-electronic platforms to ensure that they are able to keep accurate and reliable records. This will inure to their own benefit.

Further studies on other issues relating to small enterprises, taxation and record keeping may be carried out to throw more light on them. For instance the issue of income brackets and taxation of small enterprise could be examined to bring to fore the nagging issues embedded in them.

Additionally, other studies could examine the relationship between size of business and its economic importance as well as it potential to reduce unemployment.

Finally, the relationship between education, level of income, and gender could be juxtaposed with record keeping practices to determine their influence on record keeping practices.

\section{References}

Amoako, G. K. (2013). Accounting Practices of SMEs: A Case Study of Kumasi Metropolis in Ghana, International Journal of Business and Management, Canadian Center of Science and Education, 8(24)

Aryeetey, E. (2001). Priority Research Issues Relating to Regulation and Competition in Ghana. Centre for Regulation and Competition, Working Paper Series. No.10

Barr, A. (2000). Collective Action and Bilateral Interaction in Ghanaian Entrepreneurial Networks. Working Papers No. 182; UNU World Institute for Development Economics Research, Helsinki.

Beck, T., Demirguc-Kunt, A., \& Levine, R., (2003). SMEs, Growth and Poverty: Cross Country Evidence, World Bank Policy Research Working Paper

Boachie-Mensah, F. O., \& Marfo-Yiadom, E. (2005). Entrepreneurship and Small Business Management. Accra: Ghana Universities Press.

Chachage, B., \& Ngulube, P., (2006). Management of business records in Tanzania: an exploratory case study of selected companies. South African Journal of Information Management. 8(3), pp 1-18

European Commission (2008). Accounting Systems for Small Enterprises: Recommendations and Good Practices. Expert Group Report.

Everaert, P., Sarens, G., \& Rommel, J. (2006). Outsourcing of Accounting Tasks in SMEs: An extended TCE Model. Working Paper No. 2004/403. Universiteit Gent. Kuiperskaai, Belgium.

Ghana Statistical Service (2011). Preliminary Report of Population and Housing Census 2010. Ghana Statistical Service: Accra.

Gunu, U. (2004). Small Scale Enterprises in Nigeria: Their Start Up, Characteristics, Sources of Finance and Importance, Ilorin Journal of Business and Social Sciences, 9 (1 \& 2): $36-43$.

Holmes, S. \& Nicholls, D. (1989), Modeling the Accounting Information Requirement of Small Businesses, Accounting and Business Research, 19 (74) 143-150.

Holt, G. (2008). IFRS for SMEs. Student Accountant. Kaplan-ACCA. London 
Ibenta, S.N. (2005). Investment Analysis and Financial Management Strategy: Enugu Institute for Development Studies, University of Nigeria.

Ismail, N. A., \& King, M. (2007). Factors influencing the alignment of accounting information in small and medium sized Malaysian firms. Journal of Information System and Small Business, 1(1-2), 1-20.

Jayabalan, J., \& Dorasamy, M. (2009). Outsourcing of Accounting Functions amongst SME companies in Malaysia: An Exploratory Study. Accountancy Business and the Public Interest, 8(2), 96-114.

Jennings, P. D. \& Beaver, G. (1995). The performance and competitive advantage of small firms: A Management Perspective. International Small Business Journal. 15 (2): $63-75$.

Keasy, K., \& Short, H. (1990). The accounting burdens facing small firms: An empirical research note. Journal of Accounting Business Research, 20(80), 307-313.

Kyobe, M. E., Molai. P., \& Salie, T., (2009). Investigating electronic records management and compliance with regulatory requirements in a South African university. South African Journal of Information Management. 11(1), pp 1-15

Lybaert, N. (1998). The Information use in an SME: Its Importance and some Elements of Influence. Small Business Economics, 10(2), 171-191.

Maseko, N., \& Manyani, O. (2011). Accounting practices of SMEs in Zimbabwe. Journal of Accounting and Taxation, 3(8), 171-181.

Mbroh, J. K., \& Attom, E. B. (2012). Accounting and Control Systems Practiced By Small and Micro Enterprise Owners within the Cape Coast Metropolitan Area of Ghana. Asian Journal of Business and Management Sciences, 1(9), 28-47.

McCannon, J. C., (2002). Keeping Your Business on Track. Home-Based Business Fact Sheet Records, University of Maine Cooperative Extension Bulletin.

Mitchell, F., Reid, G., \& Smith, J. (2000). Information system development in the small firm: The use of management accounting. London: CIMA Publishing.

Nayak, A., \& Greenfield, S. (1994). The use of Management Accounting Information for Micro Business. In Hughes, A., \& Storey, D. (Eds.), Finance and the Small Firm. London: Routledge.

NBSSI (2009), Supporting Micro \& Small Scale Enterprises, A Handbook on Enterprise Development Part 4. NBSSI, Print Solutions, Accra.

Ofonagoro, A. O. (1983). September 30 Need for Financial Statement in Small Business. Business Times, 22.

Okoli, B. E., (2011). Evaluation of the Accounting Systems Used by Small Scale Enterprises in Nigeria: The Case of Enugu-South East Nigeria, Asian Journal of Business Management, 3(4), $235-240$

Olson, O., Blomskvisk, M., Dergard, J., \& Jonsson, C. (2004). Accounting and Entrepreneurship: A Review and Discussion of the Scientific Literature. Paper Presented at the 4th Asia-Pacific Interdisciplinary Research in Accounting Conference. 4-6, Singapore.

Quansah, P., Amankwa, E. \& Aikins, E. (2012). Influence of Micro Finance and Small Loan Centre (MASLOC) on the Development of Small Scale Enterprises in the Wa Municipality. European Journal of Business and Management, 4(1)1-10.

Schmitz, H. (1995). Collective Efficiency: Growth path for Small-scale Industry. The Journal of Development Studies, Vol. 31, No.4, pp (529-566). 
Snodgrass, D. R., \& Winkler, J. P., (2004). Enterprises Growth Initiatives: Strategic Directions and Options. Prepared for the US Agency for International Development, Bureau of Economic Growth, Agriculture and Trade. Final Report: Development Alternatives, INC (DAI).

Umar, A. B. (1997). Financing small and Medium Scale industries in Nigeria. A Paper Presented at A day Conference Survival and Development of Small and Medium Scale Industry Sector in Nigeria, Nov. P13.

Wahlstedt, K., (1996). In Search of Unbiased Accounting Measurement for Use in Small Business Management. Doctoral Thesis. Department of Economics, Swedish University of Agriculture and Science, Uppsala, Sweden

Wichman, H. (1983). Accounting and marketing-key small business problems. American J. Small Bus., 7(4), 19-26.

Williams, J. R., Haka, S. F., Bettner, M. S., \& Carcello, J. V. (2008). Financial and Managerial Accounting. New York, NY: Mc Graw-Hill Irwin. 